\title{
Respon Tanaman Pakcoy (Brassica rapa L.) terhadap Pemberian Pupuk Organik Cair Limbah Perikanan
}

\author{
Response of Pakcoy (Brassica rapa L.) to the treatment of Liquid Organic Fertilizer \\ of Fisheries Waste
}

Ahmad Rifqi Fauzi ${ }^{1 *}$, Casdi ${ }^{1}$, dan Warid ${ }^{1}$

Diterima 24 Januari 2019/Disetujui 02 April 2019

\begin{abstract}
One of issues in urban farming is waste management. The amount of waste in urban has not been managed well. Fishery waste is one of organic waste that can be utilized is as raw material for liquid organic fertilizer. The purpose of this study was to determine growth and yield responses of Pakcoy to the treatment of liquid organic fertilizer of fisheries waste. The research method was using factorial completely block randomized design repeated four times. First factor is fertilizer dosages of urea with five levels $\left(0,25 \%, 50 \%, 75 \%\right.$, and $100 \%$ from $250 \mathrm{~kg} \mathrm{ha}^{-1}$ recommendation dosage), and second factor is concentration fertilizer organic liquid fisheries waste with five levels $(0,2,4,6$, and $\left.8 \mathrm{ml} \mathrm{L}^{-1}\right)$. There are 25 treatment combinations with 6 plants per experimental unit, so there are 600 samples studied. This research was conducted at Kebun Bergizi, and Agroecotechnology Laboratory, Trilogi University, from September to October 2018. The results showed combination of 50\% treatment of urea fertilizers and $2 \mathrm{ml} \mathrm{L}^{-1}$ of organic liquid fertilizer gave better results compared to control and other treatment on growth variable. The variable of edible leaves number and fresh weight of plants ie 19.11 strands, and $220.77 \mathrm{~g}$ heavier than the $100 \%$ treatment of urea dosages used.
\end{abstract}

Keywords: Fertilization, nitrogen, organic waste, urban farming, vegetable

\begin{abstract}
ABSTRAK
Salah satu isu dalam pertanian perkotaan adalah pengelolaan limbah. Banyaknya limbah di perkotaan belum banyak dikelola secara baik. Salah satu limbah yang dapat dikelola dan dimanfaatkan adalah limbah perikanan sebagai bahan baku pupuk organik. Tujuan dari penelitian ini mengetahui respon pertumbuhan dan hasil panen pakcoy terhadap pemberian pupuk organik cair limbah perikanan. Metode penelitian menggunakan RAKL secara faktorial diulang empat kali. Faktor pertama adalah dosis pupuk urea dengan lima taraf $\left(0,25 \%, 50 \%, 75 \%\right.$, dan $100 \%$ dari dosis rekomendasi $250 \mathrm{~kg} \mathrm{ha}^{-}$ ${ }^{1}$ ), dan Faktor kedua adalah konsentrasi pupuk cair organik dari limbah perikanan dengan lima taraf $\left(0,2,4,6\right.$, dan $\left.8 \mathrm{ml} \mathrm{L}^{-1}\right)$. Terdapat 25 kombinasi perlakuan dengan 6 tanaman per satuan percobaan, sehingga ada 600 sampel tanaman yang diteliti. Penelitian ini dilakasanakan di Kebun Bergizi, dan Laboratorium Agroekoteknologi, Universitas Trilogi, pada bulan September sampai Oktober 2018. Hasil penelitian menunjukkan kombinasi perlakuan 50\% pupuk urea dan $2 \mathrm{ml} \mathrm{L}^{-1}$ pupuk cair organik memberikan hasil yang lebih baik dibandingkan dengan kontrol perlakuan lainnya pada indikator pertumbuhan. Pada peubah jumlah daun layak konsumsi dan berat segar tanaman pada kombinasi perlakuan 50\% pupuk urea dan $2 \mathrm{ml} \mathrm{L}^{-1}$ yaitu 19.11 helai, dan $220.77 \mathrm{~g}$ lebih berat dari perlakuan $100 \%$ dosis urea yang digunakan.
\end{abstract}

Kata kunci: Limbah organik, nitrogen, pemupukan, pertanian perkotaan, sayuran

${ }^{1}$ Program Studi Agroekoteknologi, Universitas Trilogi

J1. TMP Kalibata No. 1, Duren Tiga, Pancoran - Jakarta Selatan 12760

E-mail : rifqi@trilogi.ac.id (*Penulis korespondensi) 


\section{PENDAHULUAN}

Pertanian kota (urban farming) saat ini tengah populer di kalangan masyarakat kota maupun pinggiran kota. Pertanian perkotaan menurut FAO (2008) bukan hanya sekedar memproduksi dan mendekatkan pangan kepada masyarakat kota, tetapi juga dapat menggunakan kembali limbah yang berada di perkotaan sebagai upaya menjaga keberlanjutan lingkungan. Akan tetapi, permasalahan limbah menjadi isu kritis bukan hanya di kota tetapi juga nasional. Badan Pusat Statistik (2018) mencatat bahwa timbunan sampah pada tahun 2016 mencapai 6.5 juta ton dimana $48 \%$ berasal dari rumah tangga dan $60 \%$ berupa limbah organik. Kota-kota seperti Jakarta, Surabaya, dan Makasar menghasilkan sampah lebih dari 6000 ton per hari (BPS, 2018), oleh karena itu, pengelolaan limbah organik di kota dapat melalui pembuatan pupuk organik sebagai bagian dari kegiatan pertanian perkotaan. Gaya hidup masyarakat kota yang lebih menyukai produk organik, memberikan peluang besar dalam pengembangan pupuk organik karena mereka sadar bahwa penggunaan pupuk kimia pada budidaya tanaman dapat berdampak negatif baik pada kesehatan maupun lingkungan dalam jangka panjang.

Peraturan Menteri Pertanian No.70 tahun 2011 menjelaskan bahwa pupuk organik merupakan pupuk yang terdiri atas bahan organik. Firmansyah et al. (2016) menyatakan bahwa pupuk organik adalah pupuk yang berasal dari sisa tanaman, hewan atau manusia seperti pupuk kandang, pupuk hijau dan kompos yang mampu memperbaiki sifat fisik dan struktur tanah, kimia tanah, biologi tanah serta dapat meningkatkan daya menahan air dalam tanah. Salah satu tanaman sayuran yang bernilai ekonomi tinggi dan disukai masyarakat kota adalah pakcoy.

Penerapan budidaya tanaman pakcoy secara organik dapat mengurangi dampak pencemaran lingkungan karena aplikasinya tidak menggunakan bahan kimia, melainkan menggunakan bahan organik yang berasal dari limbah pertanian, peternakan, dan perikanan. Selain itu produk pakcoy organik juga memberikan nilai tambah secara ekonomi sehingga peluang penggunaan pupuk organik pada budidaya tanaman pakcoy pada masa mendatang cukup besar.
Aplikasi pupuk organik cair dari kotoran ternak dengan dosis $4 \mathrm{ml} \mathrm{L}^{-1}$ memberikan hasil yang signifikan terhadap jumlah daun, berat umbi, berat basah tanaman dan umbi kentang (Parman, 2007). Junia (2017) melaporkan bahwa pengaplikasian pupuk organik cair dari kotoran ternak dengan $6 \mathrm{ml} \mathrm{L}^{-1}$ pada budidaya tanaman sawi menghasilkan jumlah daun 11.09 helai dan berat basah $60.58 \mathrm{~g}$, sedangkan hasil penelitian Arinong dan Lasiwua (2011) menunjukkan bahwa pengaplikasian pupuk organik cair dari kotoran sapi dengan dosis 75 $\mathrm{ml} \mathrm{L}{ }^{-1}$ mampu memberikan hasil terbaik pada tinggi tanaman, jumlah daun, berat segar sawi. Informasi maupun hasil penelitian mengenai pengaruh dari pupuk organik cair limbah perikanan pada budidaya pakcoy serta dampaknya terhadap reduksi pupuk $\mathrm{N}$ anorganik belum ditemukan. Adapun penelitian lainnya menunjukkan bahwa perlakuan pupuk organik limbah ikan berpengaruh terhadap pertumbuhan jumlah daun dan tinggi tanaman cabai merah (Zahroh et al., 2018). Untuk itu, perlu dilakukan kajian terkait pengaruh pemberian pupuk organik cair limbah perikanan pada budidaya pakcoy. Tujuan dari penelitian ialah untuk mengetahui respon pertumbuhan dan hasil tanaman pakcoy terhadap pemberian pupuk organik cair dari limbah perikanan.

\section{BAHAN DAN METODE}

Penelitian ini dilaksanakan di Kebun Bergizi, Laboratorium Agroekoteknologi, Universitas Trilogi, Jakarta Selatan. Penelitian ini dilaksanakan pada bulan September sampai Oktober Tahun 2018. Penelitian ini dirancang secara faktorial menggunakan rancangan acak kelompok lengkap (RAKL) dengan jumlah ulangan 4. Faktor pertama adalah dosis pupuk urea dengan lima taraf yaitu $0 \%$ (N0), $25 \%$ (N1), 50\% (N2), $75 \%(\mathrm{~N} 3), 100 \%(\mathrm{~N} 4)$ dari dosis standar (250 kg ha-1 atau $\left.115 \mathrm{~kg} \mathrm{~N} \mathrm{ha}^{-1}\right)$, dan faktor yang kedua yaitu konsentrasi pupuk organik cair limbah perikanan dengan lima taraf yaitu $0 \mathrm{ml} \mathrm{L}^{-1}(\mathrm{~A} 0), 2 \mathrm{ml} \mathrm{L}^{-1}(\mathrm{~A} 1), 4 \mathrm{ml} \mathrm{L}^{-1}(\mathrm{~A} 2)$, $6 \mathrm{ml} \mathrm{L}^{-1}$ (A3), $8 \mathrm{ml} \mathrm{L}^{-1}$ (A4). Komposisi pupuk organik terdiri dari limbah ikan (daging, sirip, jeroan, tulang, kepala dan ekor ikan), enzim bromelin, dan larutan gula (Gambar 1). Terdapat 25 kombinasi perlakuan antara pupuk $\mathrm{N}$ an roganik $(\mathrm{N})$ dan pupuk cair organik $(\mathrm{A})$, 
dengan empat ulangan sehingga terdapat 100 satuan percobaan. Setiap satuan percobaan terdiri dari enam sampel tanaman, sehingga terdapat 600 sampel yang diamati. Setiap satuan pengamatan berupa tanaman dalam polibag berukuran $25 \mathrm{~cm} \times 25 \mathrm{~cm}$ yang telah dilubangi dan penempatannya di kebun bergizi.

Bahan yang digunakan adalah tanah, sekam, benih pakcoy varietas Nauli (F1), pupuk organik cair dari limbah perikanan, dan pupuk urea. Alat yang digunakan terdiri dari cangkul, sekop, polibag, tray persemaian, timbangan digital, penggaris, oven, dan alat tulis, kalkulator, alat dokumentasi, gelas ukur $500 \mathrm{~m} \mathrm{~L}^{-1}$, bagan warna daun (BWD). Aplikasi pupuk diberikan satu kali pada saat umur 7 hari setelah pindah tanam.

\section{Pelaksanaan Budidaya Tanaman Pakcoy}

Media tanam yang digunakan selama penelitian campuran tanah dan sekam bakar dengan perbandingan 1:1. Persemaian benih dilaksanakan satu minggu sebelum tanam. Bibit siap tanam ke polibag (transplanting) pada umur 7-10 hari setelah semai. Setiap polibag berisi satu bibit pakcoy. Penyulaman dilakukan pada bibit yang mati atau pertumbuhannya yang kurang baik. Penyiraman yang dilakukan secukupnya dilakukan pada pagi dan sore hari.

Pemberian pupuk organik dan anorganik diaplikasikan ke tanaman pakcoy yang berumur 7 hari setelah tanam. Pengaplikasian untuk pupuk $\mathrm{N}$ anorganik dengan cara dibenamkan ke dalam media tanam, sedangkan untuk pupuk organik cair diaplikasikan sesuai konsentrasi perlakuan $\left(0,2,4,6\right.$, dan $\left.8 \mathrm{ml} \mathrm{L}^{-1}\right)$ dengan cara menyiramkan pada media tanam. Pemberian pupuk dilakukan pada pagi hari. Pengendalian organisme pengganggu tanaman yang dilakukan pada gulma, hama, dan penyakit tanaman. Pemanenan dilakukan setelah tanaman pakcoy berumur 40-45 hari terhitung dari proses transplanting.

\section{Peubah Pengamatan Pada Tanaman Pakcoy}

Peubah yang diamati pada penelitian ini meliputi: kandungan pupuk cair organik, tinggi tanaman, jumlah daun, warna daun menggunakan bagan warna daun, daun layak konsumsi, dan berat segar tanaman. Data yang diperoleh diuji melalui analisis sidik ragam (ANOVA) dan diuji lanjut menggunakan uji berganda Duncan (DMRT) pada taraf kesalahan $5 \%$.

\section{HASIL DAN PEMBAHASAN}

\section{Kandungan Pupuk Organik Cair}

Pupuk organik cair (POC) yang dibuat dari limbah perikanan sebelum digunakan dianalisis terlebih dahulu. Hasil Analisis kandungan pada pupuk organik cair tersaji pada Tabel 1.

\section{Tahap Pembuatan Pupuk organik cair Limbah Perikanan}

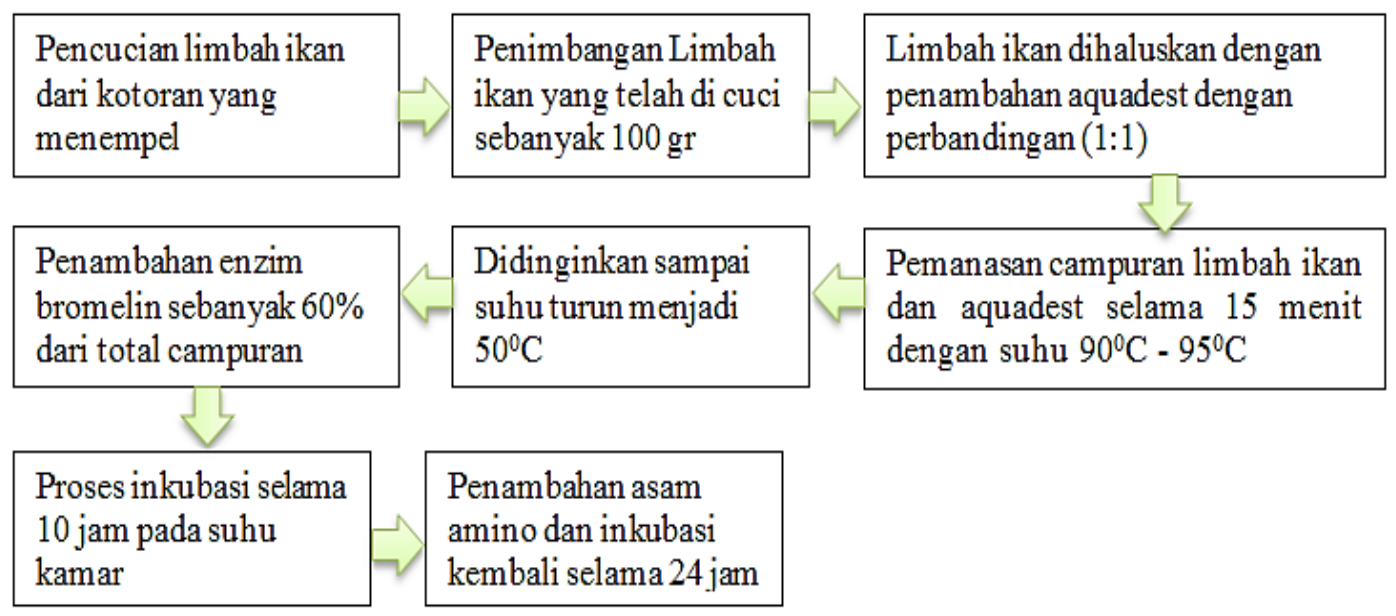

Gambar 1. Metode pembuatan pupuk organik cair telah dimodifikasi dari Hapsari dan Welasih (2011). 
Tabel 1. Hasil analisis pupuk organik cair dari limbah perikanan

\begin{tabular}{lllll}
\hline Jenis Unsur Hara & Kandungan $(\%)$ & Satuan & Standar & Satuan \\
\hline C-Organik & 6.93 & $\%$ & 6 & $\%$ \\
Nitrogen & 2.24 & $\%$ & $3-6$ & $\%$ \\
$\mathrm{P}_{2} \mathrm{O}_{5}$ & 1.91 & $\%$ & $3-6$ & $\%$ \\
$\mathrm{~K}_{2} \mathrm{O}$ & 1.81 & $\%$ & $3-6$ & $\%$ \\
\hline Jenis Mikroba & Populasi & Satuan & Standar & \\
\hline Azotobacter $s p$ & $3.5 \times 10^{6}-10^{8}$ & $\mathrm{cfu} / \mathrm{ml}$ & $\geq 10^{8} \mathrm{cfu} / \mathrm{ml}$ & \\
Azosprillium $s p$ & $1.4 \times 10^{7}-10^{9}$ & $\mathrm{cfu} / \mathrm{ml}$ & $\geq 10^{8} \mathrm{cfu} / \mathrm{ml}$ &
\end{tabular}

Keterangan: Standar berdasarkan Peraturan Menteri Pertanian No. 25 Tahun 2011

Hasil analisis menunjukkan bahwa POC limbah perikanan mengandung C-Organik (6.93\%), Nitrogen $(2.24 \%), \mathrm{P}_{2} \mathrm{O}_{5}(1.91 \%)$, dan $\mathrm{K}_{2} \mathrm{O}(1.81 \%)$. Menurut Peraturan Menteri Pertanian No. 25 Tahun 2011 Tentang Pupuk Organik, Pupuk Hayati, dan Pembenah Tanah, standar mutu untuk pupuk organik cair harus mengandung C-Organik minimal 6\%, $\mathrm{N}, \mathrm{P}_{2} \mathrm{O}_{5}$, $\mathrm{K}_{2} \mathrm{O}$ masing-masing 3-6\%. Hasil ini menunjukan bahwa pupuk dari limbah perikanan telah memilki kandungan C-Organik sesuai kriteria baku mutu yang ditetapkan, sedangkan kandungan hara lainnya masih perlu dilakukan peningkatan melalui metode ekstraksi yang tepat. Untuk memenuhi baku mutu perlu adanya penambahan variasi bahan baku yang dapat menunjang peningkatan kadar unsur hara yang menjadi parameter baku mutu pupuk organik cair.

Pupuk organik cair limbah ikan juga mengandung mikroba penambat nitrogen yaitu Azotobacter sp $\left(3.5 \times 10^{6}-10^{8} \mathrm{cfu}\right)$ dan Azosprillium sp $\left(1.4 \times 10^{7}-10^{9} \mathrm{cfu}\right)$ yang berfungsi untuk menangkap ketersediaan nitrogen di udara, sehingga dapat menyediakan hara khususnya nitrogen yang dapat mencukupi kebutuhan unsur hara bagi tanaman pakcoy. Widyawati et al. (2014) melaporkan bahwa penggunaan kedua bakteri penambat $\mathrm{N}$ tersebut mampu mengurangi $25 \%$ penggunaan pupuk $\mathrm{N}$ anorganik pada budidaya padi. Hal ini menunjukkan bahwa keberadaan mikroorganisme dalam pupuk organik cair berpotensi untuk menyediakan hara tersedia bagi tanaman ketika diaplikasikan dalam media tanam.

\section{Analisis Sidik Ragam}

Berdasarkan analisis sidik ragam hasil penelitian pengaruh kombinasi antara pupuk urea dan pupuk organik cair terhadap berbagai peubah yang diamati pada tanaman pakcoy disajikan pada Tabel 2.

Berdasarkan hasil analisis sidik ragam menunjukkan bahwa kombinasi perlakuan dosis urea dan pupuk organik cair memberikan pengaruh yang sangat signifikan pada taraf kesalahan $1 \%$ untuk semua peubah yang diamati. Hal ini menggambarkan bahwa pemberian POC limbah perikanan dapat dimanfaatkan sebagai pupuk organik pada budidaya tanaman pakcoy serta berpotensi dalam mereduksi penggunaan pupuk urea. Sehingga ketergantungan terhadap pupuk N anorganik dapat dikurangi.

Tabel 2. Rekapitulasi sidik ragam pengaruh kombinasi perlakuan dosis pupuk urea dan POC terhadap berbagai peubah yang diamati pada tanaman pakcoy umur 5 MST

\begin{tabular}{|c|c|c|c|c|c|}
\hline \multirow{2}{*}{ No } & \multirow{2}{*}{ Peubah } & \multicolumn{3}{|c|}{ F-Hitung Perlakuan } & \multirow[b]{2}{*}{ KK } \\
\hline & & Dosis Urea & POC & Urea*POC & \\
\hline 1 & Tinggi Tanaman & $26.144 * *$ & $7.344 * *$ & $4.921 * *$ & $6.94 \%$ \\
\hline 2 & Jumlah Daun & $48.060 * *$ & $6.984 * *$ & $12.199 * *$ & $6.12 \%$ \\
\hline 3 & Warna Daun & $21.744 * *$ & $7.964 * *$ & $1.944 * *$ & $5.02 \%$ \\
\hline 4 & Bobot Segar Tanaman & $64.772 * *$ & $45.256 * *$ & $46.283 * *$ & $8.92 \%$ \\
\hline 5 & Daun Layak Konsumsi & $68.804 * *$ & $11.684 * *$ & $8.563 * *$ & $8.60 \%$ \\
\hline 6 & Bobot Basah Tajuk & $63.566 * *$ & $48.128 * *$ & $44.095 * *$ & $8.89 \%$ \\
\hline 7 & Bobot Kering Tajuk & $32.340 * *$ & $21.595 * *$ & $31.756 * *$ & $10.60 \%$ \\
\hline 8 & Bobot Basah Akar & $152.912 * *$ & $405.434 * *$ & $154.275 * *$ & $6.70 \%$ \\
\hline 9 & Bobot Kering Akar & $72.651 * *$ & $178.301 * *$ & $60.805 * *$ & $11.66 \%$ \\
\hline
\end{tabular}

Keterangan: ** : Berpengaruh sangat signifikan (taraf kesalahan 1\%). 


\section{Respon Tanaman Pakcoy}

Berdasarkan hasil uji lanjut terhadap tinggi tanaman, warna daun, daun layak konsumsi, berat segar tanaman pada 5 MST, kombinasi antara 50\% dosis pupuk urea dan 2 $\mathrm{ml} \mathrm{L}^{-1}$ dosis pupuk organik cair berbeda nyata dibandingkan dengan kontrol. Tabel 3 menunjukkan pengaruh pemupukan terhadap beberapa peubah.

Perlakuan kombinasi dengan pemberian pupuk $\mathrm{N}$ anorganik sebanyak $50 \%$ dosis standar dan $2 \mathrm{ml} \mathrm{L}^{-1}$ pupuk organik cair dari limbah ikan menghasilkan tinggi tanaman tertinggi yaitu $26.50 \mathrm{~cm}$. Hal ini karenakan pengaruh unsur nitrogen yang berperan dalam pertumbuhan tanaman pakcoy. Hasil ini juga diduga kuat bahwa kombinasi tersebut mampu menyediakan unsur nitrogen yang mencukupi dan sesuai dengan kebutuhan tanaman pakcoy. Ketersediaan $\mathbf{N}$ yang cukup akan mendorong pertumbuhan dan pemanjangan sel tanaman dengan baik sehingga $\mathrm{N}$ mempunyai peran penting bagi pertambahan tinggi tanaman.

Perlakuan kombinasi dengan pemberian pupuk urea dan pupuk organik cair dari limbah ikan menunjukan bahwa perlakuan N2A1 menghasilkan nilai kehijuan daun yang berbeda nyata dibandingkan dengan kontrol dan lebih tinggi daripada penggunaan $100 \%$ nitrogen anorganik. Fauzi dan Puspitawati (2017) juga menyatakan bahwa hara $\mathrm{N}$ berperan penting dalam zat hijau daun (klorofil) yang sangat dibutuhkan dalam proses fotosintesis. Klorofil ini merupakan pigmen yang berfungsi sebagai absorben cahaya matahari yang digunakan dalam proses fotosintesis.

Tabel 3. Respon tanaman pakcoy pada perlakuan pupuk cair organik dan $\mathrm{N}$ anorganik pada peubah tinggi tanaman, warna daun, jumlah daun, dan jumlah daun layak konsumsi pada umur 5 minggu setelah tanam

\begin{tabular}{|c|c|c|c|c|c|c|c|c|c|}
\hline \multirow{3}{*}{$\begin{array}{c}\text { Perlakuan } \\
\text { NOA0 }\end{array}$} & \multicolumn{8}{|c|}{ Peubah Pengamatan pada 5 MST } & \multirow{3}{*}{$\begin{array}{c}\begin{array}{c}\text { Persentase } \\
\text { Kehilangan } \\
\text { Daun }(\%)\end{array} \\
21\end{array}$} \\
\hline & \multicolumn{2}{|c|}{$\begin{array}{c}\text { Tinggi } \\
\text { Tanaman }(\mathrm{cm})\end{array}$} & \multicolumn{2}{|c|}{ Warna Daun } & \multicolumn{2}{|c|}{$\begin{array}{l}\text { Jumlah Daun } \\
\text { (helai) }\end{array}$} & \multicolumn{2}{|c|}{$\begin{array}{c}\text { Jumlah Daun } \\
\text { Layak Konsumsi } \\
\text { (helai) }\end{array}$} & \\
\hline & 15.98 & $\mathrm{a}$ & 3.21 & $\mathrm{a}$ & 11.75 & $\mathrm{abc}$ & 9.25 & $\mathrm{abc}$ & \\
\hline N0A1 & 16.63 & $\mathrm{ab}$ & 3.88 & $\mathrm{~cd}$ & 11.13 & $\mathrm{a}$ & 9.38 & $a-d$ & 16 \\
\hline N0A2 & 17.27 & $\mathrm{ab}$ & 3.5 & $\mathrm{~b}$ & 11.29 & $a b$ & 9.04 & $a b$ & 20 \\
\hline N0A3 & 15.69 & $\mathrm{ab}$ & 3.88 & $\mathrm{~cd}$ & 10.83 & a & 8.83 & $\mathrm{a}$ & 18 \\
\hline N0A4 & 18.37 & b-e & 3.62 & bc & 12.54 & $c-f$ & 10.79 & $c-g$ & 14 \\
\hline N1A0 & 19.43 & a-d & 3.75 & bcd & 14.33 & ijk & 12.33 & ghi & 14 \\
\hline N1A1 & 20.76 & cde & 3.92 & $\mathrm{~cd}$ & 13.04 & d-g & 10.79 & c-g & 17 \\
\hline N1A2 & 18.64 & b-e & 3.71 & bcd & 13.04 & d-g & 9.79 & a-e & 25 \\
\hline N1A3 & 20.63 & b-e & 4 & $\mathrm{~d}$ & 14.04 & g-k & 11.04 & e-h & 21 \\
\hline N1A4 & 18.95 & b-e & 3.96 & $\mathrm{~cd}$ & 14.71 & $\mathrm{jk}$ & 12.46 & hi & 15 \\
\hline $\mathrm{N} 2 \mathrm{~A} 0$ & 21.47 & de & 3.96 & $\mathrm{~cd}$ & 15.75 & 1 & 14 & $\mathrm{j}$ & 11 \\
\hline N2A1 & 26.5 & $\mathrm{f}$ & 4 & $\mathrm{~d}$ & 20.29 & $\mathrm{~m}$ & 19.04 & $\mathrm{k}$ & 6 \\
\hline N2A2 & 21.03 & b-e & 3.96 & $\mathrm{~cd}$ & 13.75 & $g-j$ & 12.25 & ghi & 11 \\
\hline N2A3 & 18.72 & b-e & 3.88 & $\mathrm{~cd}$ & 15 & $\mathrm{kl}$ & 13.25 & $\mathrm{ij}$ & 12 \\
\hline $\mathrm{N} 2 \mathrm{~A} 4$ & 21.37 & $\mathrm{e}$ & 3.96 & $\mathrm{~cd}$ & 14.21 & h-k & 13.21 & $\mathrm{ij}$ & 7 \\
\hline N3A0 & 16.33 & $a b$ & 3.88 & $\mathrm{~cd}$ & 13.13 & d-h & 11.38 & e-h & 13 \\
\hline N3A1 & 19.21 & b-e & 4 & $\mathrm{~d}$ & 14.04 & g-k & 11.79 & $f-i$ & 16 \\
\hline N3A2 & 18.72 & b-e & 3.96 & $\mathrm{~cd}$ & 12.58 & $c-f$ & 10.58 & b-f & 16 \\
\hline N3A3 & 18.2 & b-e & 4 & $\mathrm{~d}$ & 14.17 & h-k & 10.92 & d-h & 23 \\
\hline N3A4 & 18.5 & b-e & 4 & d & 12.17 & bcd & 9.17 & $a b$ & 25 \\
\hline N4A0 & 18.42 & $a b c$ & 3.92 & $\mathrm{~cd}$ & 13.71 & g-j & 12.21 & ghi & 11 \\
\hline N4A1 & 18.73 & $a b c$ & 3.96 & $\mathrm{~cd}$ & 12.29 & b-e & 10.29 & $a-f$ & 16 \\
\hline N4A2 & 18.04 & b-e & 4 & $\mathrm{~d}$ & 13.13 & d-h & 9.88 & a-e & 25 \\
\hline N4A3 & 20.75 & $\mathrm{e}$ & 4 & $\mathrm{~d}$ & 13.29 & $e-i$ & 11.29 & e-h & 15 \\
\hline N4A4 & 20.31 & cde & 4 & $\mathrm{~d}$ & 13.42 & $\mathrm{f}-\mathrm{i}$ & 10.92 & d-h & 19 \\
\hline
\end{tabular}


Peningkatan pertumbuhan tanaman, sintesis protein, pembentukan klorofil yang menyebabkan warna daun menjadi lebih hijau dan peningkatan ratio pucuk akar dapat dilakukan melalui pemberian nitrogen yang optimal (Sarif et al., 2015). Semakin hijau dan daun tanaman terlihat segar, maka alat untuk melakukan fotosintesis juga semakin banyak sehingga makanan serta cadangannya yang dihasilkan lebih optimal.

Pupuk organik cair dari limbah perikanan memiliki kandungan unsur hara makro utama (N, P, dan K). Menurut Manulang et al. (2014) unsur hara makro (N, P, K, Ca, Mg, dan S) dibutuhkan tanaman dalam jumlah banyak oleh tanaman. Keenam unsur hara tersebut yang sangat penting untuk tanaman adalah unsur hara N, P dan K. Sehingga sokongan unsur hara dapat mendukung dalam peningkatan hasil produksi tanaman pakcoy, pemberian pupuk organik cair dapat memperbaiki sifat biologis tanah atau media tanam yang digunakan. Selain itu keberadaan mikroorganisme dalam pupuk organik juga menguntungkan karena berperan dalam dekomposisi bahan organik sehingga membantu dalam memperkaya hara tersedia bagi tanaman pada media tanam (Kurniawati, 2018).

Berdasarkan uji Duncan terhadap jumlah daun tanaman pada 5 MST, kombinasi antara $50 \%$ dosis pupuk $\mathrm{N}$ anorganik dan $2 \mathrm{ml} \mathrm{L}^{-1}$ pupuk organik cair berbeda nyata dibandingkan dengan kontrol dan perlakuan lainnya. Perlakuan tersebut menunjukan jumlah daun tanaman sebanyak 20.29 helai, jumlah ini menunjukan hasil lebih banyak dibanding dengan semua perlakuan (Tabel 3).

Hasil ini diprediksi kuat karena tercukupinya unsur hara nitrogen sehingga respon tanaman dalam pembentukan daun menjadi optimal. Persentase kehilangan daun yang layak konsumsi pada kombinasi perlakuan 1/2-dosis $\mathrm{N}$ anorganik $\left(125 \mathrm{~kg} \mathrm{ha}^{-1}\right)$ dengan POC limbah ikan menunjukkan yang paling rendah diantara perlakuan lainnya. Kehilangan ini diantaranya karena kerusakan oleh serangan hama dan penyakit serta daun menguning. Hal ini mengindikasikan bahwa kombinasi pemberian pupuk $\mathrm{N}$ anorganik dengan pupuk organik yang seimbang dapat menurunkan kehilangan hasil pada saat budidaya pakcoy. Pertambahan jumlah daun tanaman terjadi karena pembelahan sel, peningkatan jumlah sel dan pembesaran ukuran sel yang membutuhkan energi dalam bentuk ATP (Gardner et al., 2008).

Hasil penelitian ini menggambarkan bahwa limbah organik berbahan ikan yang berasal dari rumah tangga telah terbukti dapat digunakan sebagai nutrisi bagi budidaya pakcoy di dalam polybag dan dapat dikombinasikan dengan pupuk kimia dengan dosis yang rendah. Teknologi ini sesuai untuk praktik pertanian perkotaan yang mengedepankan ramah lingkungan. Melalui teknologi ini juga masyarakat kota dapat diajak untuk meningkatkan kesadaran terhadap lingkungan dan kesehatan. Dengan demikian pertanian perkotaan juga berperan mengurangi beban kota dalam pengelolaan sampah (Fauzi et al., 2016).

Hasil analisis korelasi antar masingmasing perubah menunjukan korelasi yang positif. Pada Tabel 4 korelasi antara tinggi tanaman berkorelasi sangat nyata terhadap jumlah daun, warna daun, berat segar tanaman, daun layak konsumsi, memiliki korelasi yang nyata.

Tabel 4. Korelasi antar peubah pengamatan pada tanaman pakcoy

\begin{tabular}{cccccc}
\hline Peubah & TT & JD & WD & BST & DLK \\
\hline TT & 1 & & & & \\
JD & $0.740^{* *}$ & 1 & & & \\
WD & $0.382^{* *}$ & $0.428^{* *}$ & 1 & & \\
BST & $0.389^{* *}$ & $0.468^{* *}$ & 0.049 & 1 & \\
DLK & $0.698^{* *}$ & $0.911^{* *}$ & $0.367^{* *}$ & $0.485^{* *}$ & 1 \\
BBT & $0.388^{* *}$ & $0.452^{* *}$ & 0.060 & $0.996^{* *}$ & $0.472^{* *}$ \\
BKT & $0.242^{*}$ & 0.193 & 0.027 & $0.866^{* *}$ & $0.217^{*}$ \\
BBA & 0.168 & 0.163 & $0.224^{*}$ & $0.428^{* *}$ & 0.195 \\
BKA & 0.106 & 0.095 & 0.163 & $0.396^{* *}$ & 0.132 \\
\hline
\end{tabular}

Keterangan: TT $=$ Tinggi Tanaman, JD $=$ Jumlah Daun, WD= Warna Daun, BST = Berat Segar Tanaman, DLK= Daun Layak Konsumsi; **= Korelasi Sangat Signifikan (Taraf 0.01); *= Korelasi Signifikan (Taraf 0.05). 
Hal ini menggambarkan bahwa semua peubah pertumbuhan, dan hasil panen menunjukan proses fotosintesis yang optimal. Fotosintesis yang optimal didukung oleh warna daun yang memiliki tingkat kehijuan yang tinggi, hijau daun dipengaruhi oleh ketersediaan $\mathrm{N}$ pada tanah atau media tanam. Sehingga pada akhirnya mendukung dari semua komponen pertumbuhan dan hasil panen yang optimal juga. Hasil korelasi ini menunjukan bahwa kombinasi antara pupuk organik cair dari limbah perikanan dan nitrogen anorganik dapat dijadikan pupuk lengkap karena kedua jenis pupuk ini dapat saling melengkapi kebutuhan unsur hara pada tanaman pakcoy khususnya hara nitrogen.

\section{KESIMPULAN}

Limbah perikanan dapat digunakan sebagai bahan utama pupuk organik cair karena mengandung unsur hara esensial yang dibutuhkan oleh tanaman. Pupuk organik cair dari limbah perikanan berpengaruh nyata terhadap tinggi tanaman, jumlah daun, daun layak konsumsi berat segar tanaman dan bobot basah tajuk dan kombinasi pemberian $2 \mathrm{ml} \mathrm{L}^{-1}$ pupuk organik cair limbah perikanan dengan $1 / 2$ dosis pupuk $\mathrm{N}$ anorganik (125 $\left.\mathrm{kg} \mathrm{ha} \mathrm{ha}^{-1}\right)$ menghasilkan produksi pakcoy yang paling baik diantara kombinasi perlakuan lainnya. Dengan demikian penggunaan pupuk organik cair limbah perikanan cukup efektif sebagai sumber unsur hara organik pada budidaya tanaman pakcoy dan dapat diaplikasikan untuk kebutuhan pertanian perkotaan.

\section{UCAPAN TERIMA KASIH}

Penulis mengucapkan terima kasih kepada Universitas Trilogi yang telah mendanai penelitian ini, kepada pihak Program studi Agroekoteknologi yang telah mendukung terlaksananya penelitian ini serta semua pihak yang membantu dalam menyelesaikan penelitian ini.

\section{DAFTAR PUSTAKA}

Arinong, A.R., C.D. Lasiwua. 2011. Aplikasi pupuk organik cair terhadap pertumbuhan dan produksi tanaman sawi. J. Agrisistem. 7(1): 1858-4330.

Augustien, N., H. Suhardjono. 2016. Peranan berbagai komposisi media tanam organik terhadap tanaman sawi (Brassica juncea L.) di polybag. Agritrop Jurnal Ilmu-Ilmu Pertanian. 14(1): 54-58.

Badan Pusat Statistik. 2018. Statistik Lingkungan Hidup Indonesia 2018: Pengelolaan Sampah di Indonesia. Jakarta: 224 Halaman.

Fauzi, A.R., M.D. Puspitawati. 2017. Pemanfaatan kompos kulit durian untuk mengurangi dosis pupuk $\mathrm{N}$ anorganik pada produksi tanaman sawi hijau (Brassica junceae). Agrotrop: Journal on Agriculture Science. 7(1): 22-30.

Fauzi, A.R., A.N. Ichniarsyah, H. Agustin. 2016. Pertanian perkotaan: urgensi, peranan, dan praktik terbaik. J. AGROTEK. 10(1): 49-62.

Firmansyah, I., L. Lukman, N. Khaririyatun, M.P. Yufdy. 2016. Pertumbuhan dan hasil bawang merah dengan aplikasi pupuk organik dan pupuk hayati pada tanah alluvial. J. Hort. 25(2): 133-141.

Food and Agriculture Organization (FAO). 2008. Urban Agriculture For Sustainable Poverty Alleviation and Food Security. $84 \mathrm{p}$.

Gardner, F.P., R.B. Pearce, R.L. Mitchel. 2008. Fisiologi Tanaman Budidaya. Terjemahan Herawati Susilo. UI Press, Jakarta.

Junia, L.S. 2017. Uji pertumbuhan dan hasil tanaman pakcoy (Brassica rapa L.) dengan pemberian pupuk cair organik pada system hidroponik. J. Agrifor. 16(1): 65-74.

[Kementan] Kementerian Pertanian. 2011. Peraturan Menteri Pertanian Nomor 70 Tahun 2011 tentang Pupuk Organik, Pupuk Hayati, dan Pembenah Tanah. 
Kurniawati, F. 2018. Pengujian kualitas kompos di Kebun Raya Cibodas terhadap pertumbuhan sawi hijau (Brassica rapa). J. Hort. Indonesia. 9(1): 47-53.

Manulang, G.S., A. Rahmi, P. Astuti. 2014. Pengaruh jenis dan konsentrasi pupuk organik cair terhadap pertumbuhan dan hasil tanaman sawi (Brassica juncea $\mathrm{L}$.) Varietas Tosakan. J. Agrifor. 13(1): 3340.

Meirina. 2014. Produksi Kedelai yang diperlakukan dengan Pupuk Organik Cair Lengkap pada Dosis dan Waktu Pemupukan yang Berbeda. Laporan Lab Biologi Struktur dan Fungsi Tumbuhan. Jurusan Biologi MIPA UNDIP.

Hapsari, N., T. Welasih. 2011. Pemanfaatan limbah ikan menjadi pupuk organik. Envirotek: Jurnal Ilmiah Teknik Lingkungan. 3(1): 1-6.

Parman, S. 2007. Pengaruh pemberian pupuk cair organik terhadap pertumbuhan dan produksi kentang (Solanum tuberosum L.). Buletin Anatomi dan Fisiologi. 15(2): 21-31.
Rahmah, A., Izzati, M. dan Parman, S. 2014. Pengaruh pupuk organik cair berbahan dasar limbah sawi putih (Brassica chinensis L.) terhadap pertumbuhan tanaman jagung manis. Buletin Anatomi dan Fisiologi. 22(1): 65-71.

Sarif, P., A. Hadid, I. Wahyudi. 2015. Pertumbuhan dan hasil tanaman sawi (Brassica juncea L.) akibat pemberian berbagai dosis pupuk urea. J. Agrotekbis. 3(5): 585-591.

Widiyawati, I., Sugiyanta, A. Junaedi, R. Widyastuti. 2014. Peran bakteri penambat nitrogen untuk mengurangi dosis pupuk nitrogen anorganik pada padi sawah. J. Agron. Indonesia. 42(2): 96-102.

Zahroh, F., K. Kusrinah, S.M. Setyawati. 2018. Perbandingan variasi konsentrasi pupuk organik cair dari limbah ikan terhadap pertumbuhan tanaman cabai merah (Capsicum annum L.). AL-HAYAT: J. Biology and Applied Biology. 1(1): 5057. 